\title{
Ervaren procedurele rechtvaardigheid in detentie
}

Kees van den Bos

Beijersbergen, K. (2014). Procedural justice in prison: a study on determinants and consequences of a procedurally just treatment of prisoners (dissertatie Vrije Universiteit Amsterdam).

In haar in 2014 aan de Vrije Universiteit Amsterdam verdedigde proefschrift Procedural justice in prison: A study on determinants and consequences of a procedurally just treatment of prisoners onderzoekt Karin Beijersbergen de rol die ervaren procedurele rechtvaardigheid speelt onder gedetineerden in Nederland. Het onderzoek heeft ze uitgevoerd aan het Nederlands Studiecentrum Criminaliteit en Rechtshandhaving (NSCR) en heeft geleid tot een graad van doctor in de rechtsgeleerdheid. Het proefschrift beschrijft op een heldere manier een goed en gedegen opgezette kwantitatieve studie. Kernbegrippen worden duidelijk uitgelegd en de studie is competent uitgevoerd. Samen met haar coauteurs heeft Beijersbergen in internationale, peer-reviewed tijdschriften over haar deelstudies gerapporteerd. Er zijn, kortom, diverse redenen waarom dit proefschrift veel lof verdient en een aanbevelenswaardig boek genoemd mag worden. Mijn complimenten aan de auteur en haar begeleiders (promotoren Peter van der Laan en Paul Nieuwbeerta en copromotor Anja Dirkzwager)!

Zoals de auteur zelf toegeeft, wordt ervaren procedurele rechtvaardigheid in dit proefschrift breed gedefinieerd. De auteur stelt dat er sprake is van een procedureel rechtvaardige bejegening van gedetineerden door gevangenisautoriteiten indien de gedetineerden van mening zijn dat er in detentie (1) rechtvaardige (bijv. onpartijdige en consistente) procedures worden toegepast, (2) zij respectvol en humaan worden behandeld, en (3) de omgang met penitentiaire inrichtingswerkers (PIW'ers) positief en constructief is. De auteur merkt terecht op dat er niet een algemeen geaccepteerde schaal is om ervaren procedurele rechtvaardigheid te meten. Het is dan ook alleszins te billijken om de hier gebruikte algemene operationalisatie van ervaren procedurele rechtvaardigheid te aanvaarden. Dat gezegd hebbende, iets meer reflectie (in inleiding en/of discussie) op de relatie tussen de gemeten concepten en andere schalen die in de literatuur zijn gerapporteerd, was wellicht op haar plaats geweest (zie bijv. Lind \& Tyler, 1988; zie ook het recent verschenen artikel van Enoksen, 2015). Maar, nogmaals, de hier gekozen definitie en uitwerking van ervaren procedurele rechtvaardigheid zijn goed en deugdelijk.

Het onderzoek maakt gebruik van longitudinale data die verzameld zijn in het kader van het 'Prison Project'. Dit is een indrukwekkend project waarbij een representatieve steekproef van 1.909 volwassen mannelijke gedetineerden in Nederland is bevraagd over diverse zaken tijdens hun detentie. Het proefschrift richt zich hierbij op ervaringen van (deelsteekproeven van) gedetineerden die op twee tijdstippen werden gemeten, namelijk drie weken en drie maanden nadat zij 
werden ingesloten in een huis van bewaring. Naast deze zelfrapportage werden ook disciplinaire rapporten van de gedetineerden in het onderzoek betrokken evenals architectonische kenmerken van de penitentiaire inrichtingen (PI's) plus kenmerken van de PWI'ers. Nogmaals, dit is een indrukwekkend project, al zou het wellicht te overwegen zijn om het niet als het 'Prison Project' aan te duiden, maar iets meer gespecificeerd als bijvoorbeeld het 'NSCR Prison Project' of het 'Netherlands Prison Project'. Er zijn tenslotte meerdere gevangenisstudies uitgevoerd (zie bijv. Zimbardo, 2007).

De verschillende deelstudies laten interessante bevindingen zien. Zo wordt onder meer aangetoond dat op afdelingen waar meer vrouwelijke PIW'ers werkzaam zijn gedetineerden een hogere mate van procedurele rechtvaardigheid ervaren. Dit zou onder meer te maken kunnen hebben met het feit dat vrouwen meer betrokken zijn bij anderen. Ook is het zo dat op afdelingen waar PIW'ers positiever staan tegenover resocialisatie, gedetineerden positiever oordelen over hun relaties met PIW'ers. Misschien komt dit omdat PIW'ers met een positievere attitude ten aanzien van resocialisatie meer sociale steun bieden aan gedetineerden.

Een interessante bevinding is voorts dat op afdelingen waar meer PIW'ers werken ook meer procedurele rechtvaardigheid wordt ervaren, wellicht omdat PIW'ers dan meer contacten met gedetineerden kunnen onderhouden en minder werkdruk ervaren. Hierbij aansluitend wordt ook gerapporteerd dat de wijze waarop huizen van bewaringen zijn gebouwd van invloed is op de procedurele rechtvaardigheid die wordt ervaren. Zo lijkt het erop dat wanneer de architectuur van de huizen van bewaring meer contacten tussen PIW'ers en gedetineerden toestaat er een hogere mate van ervaren procedurele rechtvaardigheid werd waargenomen.

Deze en andere bevindingen zijn interessant en leveren diverse concrete zaken op waar in beleid wat mee gedaan kan worden. Aangetekend moet wel worden dat de bevindingen die worden gerapporteerd veelal voor meerdere interpretaties vatbaar zijn. De door de auteur gekozen interpretatie snijdt veelal hout, maar een duidelijke tekortkoming van het onderzoek lijkt het ontbreken van aanvullende gegevens te zijn waarmee deze interpretatie kan worden onderbouwd en alternatieve interpretaties kunnen worden verworpen. Ook was wellicht iets meer reflectie op haar plaats geweest op het feit dat de interpretatie van longitudinale studies uiteindelijk toch veelal een beroep moet doen op correlationele relaties waarbij de duiding van associaties tussen gemeten constructen een belangrijke rol speelt.

Nogmaals, de beleidsimplicaties van dit onderzoek worden goed en gedegen over het voetlicht gebracht. De bespreking van de wetenschappelijke implicaties van dit academische proefschrift is relatief wat onderbelicht en had meer aandacht verdiend. Zo heeft de auteur het regelmatig over 'de procedurele rechtvaardigheidstheorie'. Dit is een term die men vaker tegenkomt in juridische geschriften naar ervaren procedurele rechtvaardigheid. Het is wellicht goed om op te merken dat deze term niet helemaal terecht is. Ervaren procedurele rechtvaardigheid kan diverse effecten op mensen hebben en de procedurele rechtvaardigheidsliteratuur beschrijft deze effecten (zie bijv. Tyler, 2006; Van den Bos, 2015). Voorts zijn er diverse theorieën opgesteld om deze effecten te duiden (zie bijv. Brockner \& Wiesenfeld, 1996; Folger, 1987; Lind \& Tyler, 1988; Van den Bos \& Lind, 2002). Deze 
theorieën doen verschillende voorspellingen over de omstandigheden waaronder ervaren procedurele rechtvaardigheid effecten heeft op menselijke reacties en waarom dit het geval zou zijn.

Het is dus onjuist om te spreken van 'de procedurele rechtvaardigheidstheorie' en het was aanbevelenswaardig geweest als de auteur was nagegaan welke theoretische verklaring voor de door haar gevonden resultaten in haar gevangenisonderzoek het meest van toepassing is en waarom. Dit had de wetenschappelijke relevantie van haar onderzoek voor de psychologie, de juridische en de criminologische wetenschap vergroot. Ook had een dergelijke bespreking aangetoond dat de ervaring van boosheid een centraal onderdeel vormt van in ieder geval een procedurele rechtvaardigheidstheorie (Folger, 1987), iets wat de auteur nu over het hoofd heeft gezien. En het had de beperkingen in voornoemde theorieën duidelijker kunnen blootleggen dan thans het geval is. De onderzoeksbevindingen in deze belangwekkende dissertatie zijn er interessant genoeg voor!

Concluderend, niettegenstaande de kritische puntjes die in deze bespreking aan bod zijn gekomen, is dit een belangwekkend en competent uitgevoerd proefschrift, dat het lezen waard is voor zowel beleidsmakers als wetenschappers.

\section{Literatuur}

Bos, K. van den (2015). Humans making sense of alarming conditions: psychological insight into the fair process effect. In: R.S. Cropanzano \& M.L. Ambrose (eds.). Oxford handbook of justice in work organizations. New York: Oxford University Press, 403-417.

Bos, K. van den \& Lind, E.A. (2002). Uncertainty management by means of fairness judgments. In: M.P. Zanna (ed.). Advances in experimental social psychology (Vol. 34). San Diego, CA: Academic Press, 1-60.

Brockner, J. \& Wiesenfeld, B.M. (1996). An integrative framework for explaining reactions to decisions: interactive effects of outcomes and procedures. Psychological Bulletin, $120,189-208$.

Enoksen, E. (2015). Examining the dimensionality of Colquitt's organizational justice scale in a public health sector context. Psychological Reports, 116, 723-737.

Folger, R. (1987). Reformulating the preconditions of resentment: a referent cognitions model. In: J.C. Masters \& W.P. Smith (eds.). Social comparison, social justice, and relative deprivation: theoretical, empirical, and policy perspectives. Hillsdale, NJ: Erlbaum, 183-215.

Lind, E.A. \& Tyler, T.R. (1988). The social psychology of procedural justice. New York: Plenum. Tyler, T.R. (2006). Why people obey the law. Princeton, NJ: Princeton University Press.

Zimbardo, P.G. (2007). The Lucifer effect: understanding how good people turn evil. New York: Random House. 